Proceedings of the International Conference on Teaching, Education and Learning Conference, Vol. 1, 2021, pp. 1-13

Copyright (C) 2021 iConferences

ISSN 2820-2155

DOI: https://doi.org/10.32789/tel.2021.1001

\title{
Need of BYOD in Mobile Learning Usage Among Enforcement Officer at MDTCA Malaysia
}

Noor Husna Sharuddin ${ }^{1}$, Mariam Mohamad ${ }^{1}$, Irwan Mahazir Ismail ${ }^{1}$

${ }^{1}$ Universiti Sains Malaysia,noorhusna@kpdnhep.gov.my,.mmohamad@usm.my, irwan_mahazir@usm.my 


\title{
NEED OF BYOD IN M-LEARNING USAGE AMONG ENFORCEMENT OFFICERS AT MDTCA MALAYSIA
}

\begin{abstract}
M-Learning using BYOD is an effective learning medium that will be developed to support enforcement officers at the Ministry of Domestic Trade and Consumer Affairs (MDTCA) Malaysia. Nevertheless, the problem statement study identified workload and constraints, limited training, and limited reference sources, which will be discussed in this article. Therefore, this study will face problem statements and examine the effect of mobile learning BYOD with different job positions view. To evaluate the level of acceptance and use of the application POT@MDTCA, the researchers applied the UTAUT2 constructs in the study. This study is qualitative in a nature case study. Methodology interviews were conducted with six respondents from different job positions at MDTCA Penang. This study showed that mobile learning with the "BYOD" concept is needed to achieve individual competencies in enforcement. The researchers have identified the rationale of the mobile learning BYOD concept is needed by enforcement officers to increase skills in learning opportunities development. The implications of this study will be significant to improve competency course achievement in knowledge and skills of enforcement to all MDTCA Malaysia.
\end{abstract}

Keywords: Enforcement, BYOD, M-Learning, UTAUT2

\section{Introduction}

The M-Learning approach is growing rapidly as a learning technology. M-Learning provides the concept of a new learning approach where learning style using mobile devices. Mobile learning is becoming increasingly popular due to its more flexible use and ability to minimize training costs in an organization (García et al. 2019). The study aims to see the rationality of courses among MDTCA enforcers through M-Learning with the concept of BYOD. This study will also identify whether MDTCA enforcers need the courses in M-Learning as a medium of continuous learning. M-Learning will also be used as a reference center related to the MDTCA Act and standard operating procedure MDTCA (2021a) for knowledge sharing to the enforcement. Enforcers can also improve the achievement of competency course attendance by attending courses through M-Learning with this BYOD concept.

A lot of workload and constraints are a rationale that needs to be addressed to avoid decreased productivity of work results. This is because the burden of daily official duties also restricts enforcers from attending any training that traditional learning needs to be followed. Excessive workloads are among the reasons why adult learners delay the desire to pursue professional training (Yin Ling et al. 2018a). Limited course offers are a problem for enforcers to improve their skills in mastering the MDTCA Act (MDTCA, 2021b). Enforcement involves three enforcement groups, namely Enforcement Officer, Assistant Enforcement Officer, and Enforcement Assistant. Training offers among enforcers are limited, and they are also burdened with the current task of attending training organized outside the office. Through this, M-Learning provides an opportunity for enforcers to follow courses with various learning methods. This statement support Assen Marcel F. Van; Albloush Ahmad et al. (2020), where improvements for continuous training must be conducted through methods of improvement, including 
theoretical and practical components taking into account the interests of individuals and organizations for strategic improvement. Enforcers do not only need to attend class training but also can follow the M-Learning through BYOD concept.

M-Learning is a various teaching and learning method that can be practiced in the development of the modules. This includes information sharing, which is related to the Act, Standard Operating Procedure, and course notes (MDTCA, 2021c). According to Ardi Syed and Dr. Zaidatun et al. (2017), easy to access the notes courses through M-Learning sharing by simply using the broadband service provided by the subscribed mobile phone provider to download anytime and anywhere when needed. Content in mobile learning includes interactive multimedia materials, accessing notes, and assessments containing multimedia elements such as a combination of graphics, text, audio, video, and interactivity (Yuen et al. 2018a). Therefore, the availability of online reference sources allows enforcers to access the notes when conducting inspections. Reference sources that can be made as a guide for enforcement activities when needed.

The UTAUT2 theory was used in this study to determine the level of acceptance and use of the application POT@MDTCA, which consists of seven independent variables, including performance expectancy, effort expectancy, facilitating conditions, social influence, hedonic motivation, price value, and habits (Venkatesh et al., 2012). According to Venkatesh et al. (2016), user behavioral intentions in using technology. As a solution, the researcher used behavioral intention as the study's dependent variable and one moderator related to the experience of using M-Learning.

\section{Literature Review}

In this study, the population consists of three groups of various enforcement officer positions, including 281 individuals in the position of Enforcement Assistant, 176 individuals in the position of Assistant Enforcement Officer, and 45 individuals in the position of Enforcement Officer. The study's respondents of this research were involved is depicted in Table 1 below:

Table 1: Type of Respondents

\begin{tabular}{lcccc}
\hline Positions & Number & Preliminary Study & Pilot Study & Data Collection \\
\hline Enforcement Officer & 45 & 2 & 10 & 30 \\
\hline $\begin{array}{l}\text { Assistant Enforcement } \\
\text { Officer }\end{array}$ & 176 & 2 & 10 & 30 \\
\hline Enforcement Assistant & 281 & 2 & 10 & 30 \\
\hline
\end{tabular}

BYOD is a new learning medium where enforcers need to use BYOD or personal devices to follow courses through Pocket Online Training developed. As many as $66.5 \%$ of the government sector adopts BYOD compared to only $33.5 \%$ in the private sector Majid et al. (2018) with different learning environments regarding place, time, and circumstances. BYOD allows employees to use their devices to access an organization's resources to perform their work (Mahat and Ali, 2018). The Penang State Director of MDTCA allows the use of BYOD in the workplace to access and follow training through the POT@MDTCA application.

M-Learning is defined in a range of ways throughout the literature. Mobile learning is a specific learning model using various types of mobile technology (Yuen S. C. et al. 2018b). M-Learning increases 
interest in mobile learning, using devices varying in size from the large, such as netbooks, notebooks, and laptops, to small, like mobile phones and PDAs (Mohamad Mariam et al. 2012). Supported by Samed Ahmad et al. (2018), mobile devices can connect to the Internet to deliver instructions and materials to students anytime and anywhere. M-Learning is a self-learning concept where learning can be accessed through various mobile technologies, and learning can be followed anytime and anywhere.

Seven independent variables, one dependent variable, and one moderator variable will define the scope of its use in this study (Chang, 2012). The performance expectancy constructs in this study relate to the evaluation of training offers through the POT@MDTCA application. The second construct of effort expectancy is related to a clear and easy-to-understand application module design. The third construct of social influence is related to the recommendation to pursue M-Learning training either through the leader, colleagues or self-initiative to follow it. Following that, to simplify the issue, facilitating conditions constructed in this application is connected to training and can be accessible by BYOD or other technology with an internet connection. The hedonic motivation construct is associated with the suitability of the application, where it is loaded with activities such as animated videos, quizzes and exercises. The price value construct is based on the benefits experienced by Enforcement Officers when utilizing the application, even if it requires access via a personal device and the cost of an internet purchase. The habit construct is based on Enforcement Officers' performance tendencies toward their behavior to use M-Learning as a medium for professional training through an application developed. The study's theoretical framework is depicted in diagram 1 below:

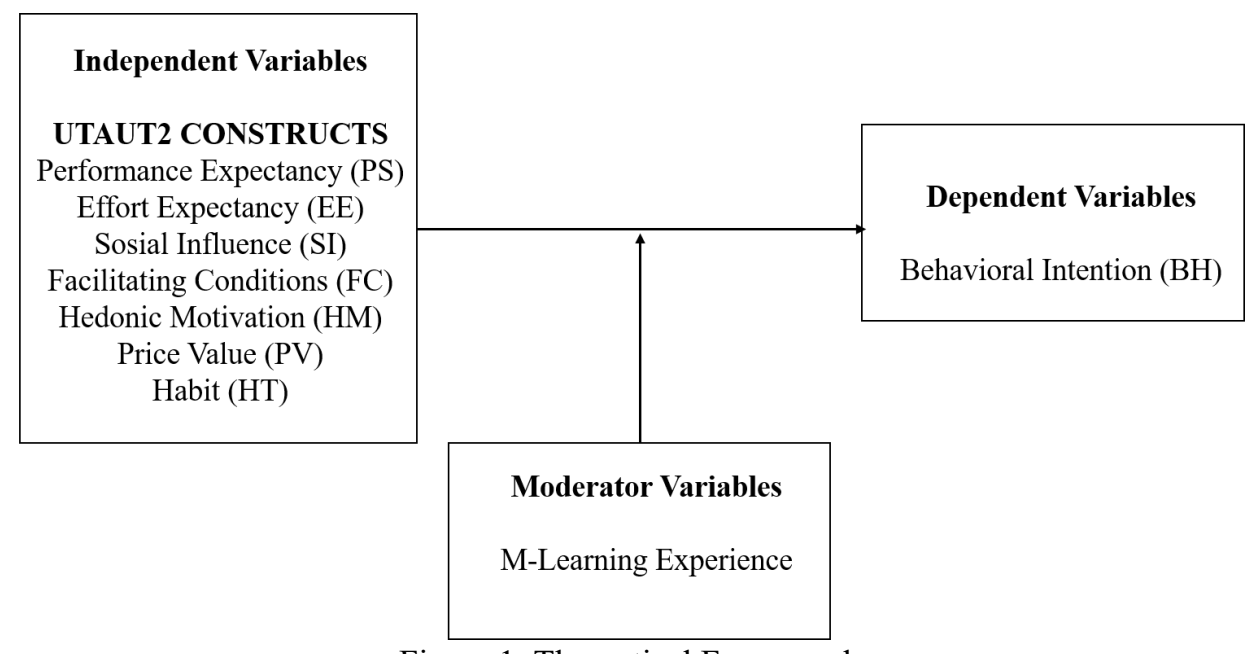

Figure 1. Theoretical Framework

\section{Methodology}

This study is a qualitative method research design case study. In the study, validity and reliability are emphasized. Two experts in the field of instructional technology and multimedia with 13 and 21 years of experience in the field evaluated and verified a semi-structured interview instrument with 19 questions. Purposive sampling is used to access a specific subset profile with homogeneous techniques (Etikan I. 2016). Participants are chosen based on the rationale that they would fulfill the purpose of the study. The data was collected via interviews with six respondents from different positions and two respondents from the management section (Huang, 2020). Researchers used interview data, annual course schedules, and examination records to conduct a triangulation analysis on the subject (Zakaria N. 2019). This data was verified verification of information by the respondent after the data was 
transcribed for content validity. Next, the data is analyzed to the theme based on the study's research objectives, where are the requirements for the development of M-Learning courses as a BYOD practice among officers at MDTCA.

Table 2: Techniques for conducting a preliminary study and respondent

\begin{tabular}{|c|c|c|c|c|}
\hline Activities & Strategy & Technic & Respondents & Job Positions \\
\hline \multirow{6}{*}{$\begin{array}{l}\text { Preliminary } \\
\text { study }\end{array}$} & \multirow[t]{6}{*}{ Case study } & \multirow{4}{*}{$\begin{array}{l}\text { Semi-structured } \\
\text { interviews }\end{array}$} & 2 & Enforcement Officer \\
\hline & & & 2 & Assistant Enforcement Officer \\
\hline & & & 2 & Enforcement Assistant \\
\hline & & & 2 & Management Section \\
\hline & & \multicolumn{3}{|c|}{ Annual course schedule } \\
\hline & & \multicolumn{3}{|c|}{ Examination records } \\
\hline
\end{tabular}

\section{Semi-Structured Interview Instruments}

Researchers have developed 19 questions related to the experience, current knowledge and expectations to M-Learning with two experts in the fields of instructional technology and multimedia have validated a total of 19 research questions for preliminary study through a semi-structured interview. The research questions in table 3 below have been revised based on expert recommendations and views:

\section{Table 3: Semi-Structured Interview Questions for Preliminary Study}

\begin{tabular}{|c|c|}
\hline $\begin{array}{l}\text { 1. Have you attended a course online using your } \\
\text { devices? }\end{array}$ & $\begin{array}{l}\text { 11. Do you agree if the knowledge sharing module } \\
\text { related to the MDTCA Act, Guidelines, SOPs and } \\
\text { other information is added to this M-Learning } \\
\text { module? }\end{array}$ \\
\hline $\begin{array}{l}\text { 2. Do you find it difficult to attend any of the } \\
\text { department's courses? }\end{array}$ & $\begin{array}{l}\text { 12. Will this M-Learning that will be developed help } \\
\text { you in your daily tasks as well as improve your most } \\
\text { productive work performance? }\end{array}$ \\
\hline $\begin{array}{l}\text { 3. Have you ever been offered a course by your } \\
\text { department? }\end{array}$ & $\begin{array}{l}\text { 13. Do you agree that this developed M-Learning can } \\
\text { be accessed using your devices? }\end{array}$ \\
\hline $\begin{array}{l}\text { 4. Have you ever attended a course related to the } \\
\text { MDTCA Act? }\end{array}$ & $\begin{array}{l}\text { 14. Do you agree that MDTCA should adopt M- } \\
\text { Learning for all enforcers? }\end{array}$ \\
\hline 5. What MDTCA Act courses have you attended? & $\begin{array}{l}\text { 15. Do you agree to access M-Learning using your } \\
\text { own data and internet? }\end{array}$ \\
\hline $\begin{array}{l}\text { 6. Are the MDTCA Act courses you attended } \\
\text { adequate? }\end{array}$ & $\begin{array}{l}\text { 16. In your opinion, can mobile learning attract the } \\
\text { interest of enforcers to follow this course? }\end{array}$ \\
\hline $\begin{array}{l}\text { 7. Are you knowledgeable about all of the } \\
\text { MDTCA's laws? }\end{array}$ & $\begin{array}{l}\text { 17. Is using your devices a major problem for you to } \\
\text { follow the M-Learning that will be developed later? }\end{array}$ \\
\hline $\begin{array}{l}\text { 8. Are you proficient in 5P to enforce the MDTCA } \\
\text { Act? }\end{array}$ & $\begin{array}{l}\text { 18. Do you often use your devices to access official } \\
\text { department data? }\end{array}$ \\
\hline $\begin{array}{l}\text { 9. What are the reference sources, and when do } \\
\text { you make an inspection in the field? }\end{array}$ & $\begin{array}{l}\text { 19. Do you plan to participate in a future M-Learning } \\
\text { will be developed? }\end{array}$ \\
\hline $\begin{array}{l}\text { 10. Do you agree if courses related to the MDTCA } \\
\text { Act to improve 5P Enforcement skills are } \\
\text { developed through M-Learning and access through } \\
\text { your devices? }\end{array}$ & \\
\hline
\end{tabular}




\section{Theme}

The study's ethical problem is the attitude of the enforcement officers, who decide whether or not to attend or follow the courses provided to them to improve their knowledge and skills. As a result, this research can look at an officer's attitude on whether or not to follow the planned training. The first theme found in this study is the difficulty attending traditional training due to a heavy workload and the difficulties of attending training outside of the workplace. The next theme is related to the limited training offer to Enforcement Officers. The last theme of this paper is that searching for work-related material is challenging due to the lack of a centralized reference source. The theme of this study is depicted in diagram 2 below:

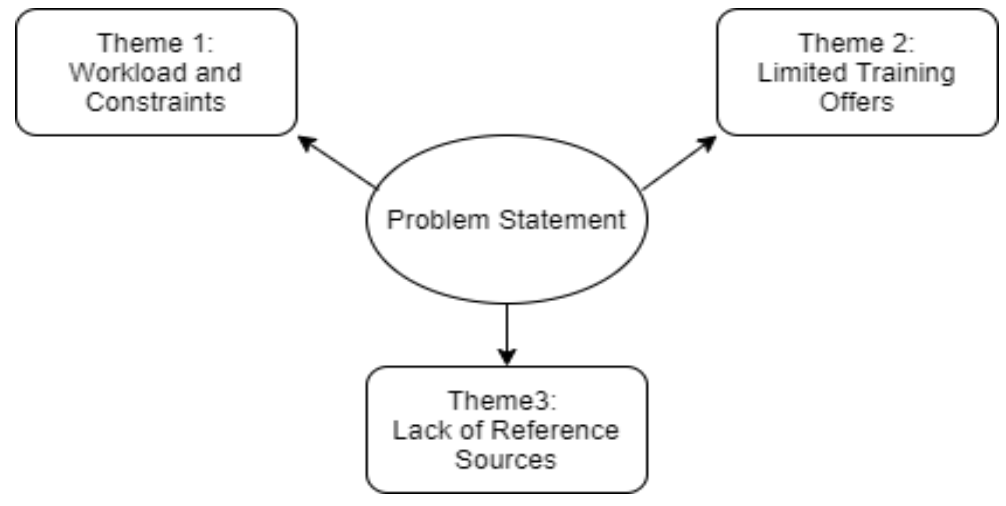

Figure 2. Theme

Findings

The need for M-Learning through the BYOD concept is due to workload and constraints.

The interview data obtained shows that MDTCA enforcers need courses using the M-Learning BYOD concept. This is due to the daily workload that makes it difficult for them to attend courses in the classroom.

The results of the interview respondents stated problems related to courses at MDTCA as follows:

"The courses offered need to use your money first. The costs required for accommodation costs, travel costs and food costs to take courses and training outside the office." (Respondent 2 from the position of Enforcement Assistant).

"Now, the issue of not being able to attend courses and training at MDTCA is due to the overload of workload. Due to the workload task given, it is very difficult for enforcers to attend courses offered outside the office." (Respondent 4 from the position of Assistant Enforcement Officers).

"The time for enforcers to learn an Act is limited due to the many official work that needs to be done. When there is a course through M-Learning, this helps the enforcers to learn the Act." (Respondent 5 from the position of Enforcement Officers). 
"Too many tasks given make it difficult for enforcers to attend the course and training outside the office, which is of constraint to the enforcers. In addition to that, the current situation where movement is limited to attending a course organized outside the office." (Respondent 6 from the position of Enforcement Officers).

\section{The need for M-Learning through the BYOD concept is due to limited training offers.}

The findings of the interview analysis data related to limited training offer to enforcers justify the necessity to have courses in M-Learning through the BYOD concept. On average, only ten offers of courses in a year were conducted under the organization of MDTCA headquarters. There are no training offers organized by MDTCA at the state level. The location for the courses organized is only according to the zones, for example, the northern zone which involves the States of Perak, Penang, Kedah, and Perlis, and selected one state as a location centrally representing the north zone.

The results of the interview with respondents stated that the number of course offerings is limited and only offered by headquarters, as follows:

"Stated that in a year, only six to eight courses are offered at the headquarters to all MDTCA enforcers in Malaysia. But, if there are courses online, this is good because now there is no course offered." (Respondent 4 from the position of Assistant Enforcement Officers).

"The frequency of courses organized by headquarters related to enforcement is around 10 courses in a year. Also, now in the pandemic season, there is no offer of enforcementrelated courses at all." (Respondent 5 from the position of Enforcement Officers).

"If I work in Penang, then my course will be offered and organized in the northern zone. The northern zone involves the States of Perak, Penang, Kedah, and Perlis." (Respondent 6 from the position of Enforcement Officers).

\section{The need for M-Learning through the BYOD concept is due to a lack of reference sources.}

The interview data shows that MDTCA enforcers need reference material related to the Act MDTCA (2021d) to guide inspection and enforcement activities. Previously, if there were any problems related to the Act when the inspection was done, enforcers would refer to the head of the unit as a reference to the Act. These references and guides are not only used for enforcement activities but as a guide in preparation for exams, especially job confirmation exams and career enhancement courses. Sharing information on the concept of M-Learning using BYOD helps enforcers to improve their knowledge and inspection skills where enforcers will be better prepared with knowledge through personal devices when dealing with customers in the inspections area.

The results of the interview with two respondents stated that there are no reference sources related to enforcement during the inspection conducted in the field as follows:

"While in the field, if there is any problem related to the Act, we have to contact the head of the unit to refer. Such as inspection information related to compounds and offenses that need to be determined."(Respondent 4 from the position of Assistant Enforcement Officers). 
"M-Learning is suitable for reference of current tasks in the field because through

handphone; enforcers can access all the necessary information and references."

(Respondent 6 from the position of Enforcement Officers).

\section{Summary of Study Findings}

Table 4: Summary of Findings

\begin{tabular}{|c|c|c|}
\hline Respondent & Arguments & Theme \\
\hline $\mathrm{R} 2$ & $\begin{array}{c}\text { The workload has made it difficult for enforcers to attend courses } \\
\text { offered outside the office. }\end{array}$ & $\begin{array}{l}\text { Workload and } \\
\text { constraints }\end{array}$ \\
\hline \multirow[t]{3}{*}{$\mathrm{R} 4$} & $\begin{array}{l}\text { Off-office courses require costs including accommodation costs, travel } \\
\text { costs, and food costs }\end{array}$ & $\begin{array}{l}\text { Workload and } \\
\text { constraints }\end{array}$ \\
\hline & $\begin{array}{l}\text { The frequency of the number of courses related to the act is between six to } \\
\text { eight in a year. }\end{array}$ & Training Limited \\
\hline & $\begin{array}{l}\text { Need to refer to the head of the unit if there are any problems related to the } \\
\text { Act, for example, references related to offenses and compounds that need to } \\
\text { be set. }\end{array}$ & $\begin{array}{l}\text { Limited reference } \\
\text { sources }\end{array}$ \\
\hline \multirow[t]{2}{*}{ R5 } & Enforcers do not have time to study an Act due to many official duties. & $\begin{array}{l}\text { Workload and } \\
\text { constraints }\end{array}$ \\
\hline & $\begin{array}{c}\text { On average, the courses organized by the headquarters are around } 10 \\
\text { courses in a year, and now in the pandemic season, there are fewer courses } \\
\text { offer. }\end{array}$ & Training Limited \\
\hline \multirow[t]{3}{*}{ R6 } & $\begin{array}{l}\text { Official duties in the units are a lot, so that too difficult for enforcers to } \\
\text { attend courses outside the office. Also, the movement now is limited to } \\
\text { attending courses outside. }\end{array}$ & $\begin{array}{l}\text { Workload and } \\
\text { constraints }\end{array}$ \\
\hline & $\begin{array}{l}\text { Course offers are by zone; for example, the northern zone involves the } \\
\text { States of Perak, Penang, Kedah, and Perlis. }\end{array}$ & Training Limited \\
\hline & $\begin{array}{l}\text { M-Learning as a medium through the BYOD concept is to access the } \\
\text { information and reference during the inspections. }\end{array}$ & $\begin{array}{l}\text { Limited reference } \\
\text { sources }\end{array}$ \\
\hline
\end{tabular}

Table 4 shows the respondents' feedback related to the needs for M-Learning through the BYOD concept to the enforcement. Feedback respondent R2 related to the theme of constraints and a lot of workloads is one of the factors for this M-Learning needs to enforcers where they can practice the course by using BYOD without having to attend courses outside the office. Another theme due constraints and workload because a lot of official duties that cause it difficult for enforcers to attend courses outside the office, limited time to study the Act, and movement restriction to attend courses outside the office.

Meanwhile, feedback related to the theme of limited training offers was argued by respondents R4, R5, and R6. They also said that the course only organized by the headquarters is according to the zones that have been set. Among the northern zones involving the States of Perak, Penang, Kedah, and Perlis. On average, only 10 courses in a year have been organized by headquarters according to the positions and zones involved.

Next, the theme is related to the unavailable source of reference to the enforcers to be used as a guide during the inspection. This theme was argued by respondents R3, R4, and R6, where they stated that the reference of the Act is required during the inspection to determine the types of offenses and the determination of the compound rate to be set. Therefore, with the existence of M-Learning through the 
BYOD concept, it makes it easier for the enforcers to access all the information related to the inspection until the process of determining the compound rate in the field is easy to access by using the BYOD enforcers only.

\section{Discussions}

\section{The need for M-Learning through the BYOD concept is due to workload and constraints}

These findings show that excessive constraints and workload can cause stress at work. That is why enforcers cannot attend courses outside the office where courses are through in the learning classroom. This study is supported by Tran et al. (2020a), who stated that the stress from workload is an effect due to much workload and efficiency factors in performing a task. While Daniel (2020) stated the major sources of stress were inadequate pay, inequality at work, workload, staff shortage, lack of promotion, job insecurity, and lack of management support and Tran et al. (2020b) stated that workload is also defined as the number of tasks that need to be performed by a system in a given period.

These findings show that the M-Learning concept can help enforcers follow the courses. The new learning environment and work environment will help enforcers in improving knowledge and skills related to enforcement. The ease of use of an M-Learning system can add value to the existing learning management system improvement of learning acceptance toward M-Learning Weeger et al. (2018). According to Nasir Mohd and Zolkiply Hazariah (2017), management needs to prepare a more conducive work environment and meet the needs of employees to work in an organization that can be a medium of support system to the employees. M-Learning through the BYOD concept has opened up space and opportunities with a new and more conducive learning method environment for enforcers to follow courses.

Therefore, the availability of M-Learning courses through the BYOD concept can reduce the workload, and enforcers will be more eager to follow the courses. Supported that Mohd Norazlin and Rahaimah Siti (2019) said that the need to implement new teaching strategies, fun and meaningful with appropriate resources, can improve the quality of learning. In addition to improving the knowledge and skills related to the Act, the quality of work productivity in the inspections area can be produced by enforcers with the sharing of information obtained through the BYOD concept. Enforcers will not worry if not be able to attend courses outside the office because, through the M-Learning course, it can reduce the workload of enforcers to attend courses outside the office.

\section{The need for M-Learning through the BYOD concept is due to limited training offers.}

The findings show that limited training offers to enforcers to follow courses related to the enforcement Act MDTCA (2021e) is an issue of why M-Learning is needed. The study is supported by Rodriguez \& Walters (2017) where it stated that training for employees would assist the organization and employees in achieving various goals, such as increasing morale, sense of security, employee engagement, and overall competencies needed to perform a particular job. In this study, the use of Mlearning is a new stage in the development of e-learning and distance learning and also as a new technology used as an aid for teaching and learning (Safie et al., 2018). Previously, the estimated courses offered in a year were only 10 courses. The course is divided according to zones, for example, the northern zone involving the states of Perak, Penang, Kedah, and Perlis. Centralized course centers will be selected from the zone states for the course to be conducted. Opportunities to attend the course 
are also limited due to only enforcers that got offered can attend the course. Enforcers have to wait for their turn to take courses related to Acts and enforcement (MDTCA, 2021f).

Therefore, the need for courses through M-Learning methods not only can improve the knowledge and skills of enforcers but can indirectly improve the quality and productivity of an organization. Supported that Rafiq et al. (2020) even though half of the adult learners in this study were not confident in the dependability of M-Learning courses, but the final findings revealed that M-Learning provides a training alternative for employees to enhance communication skills. In support, Basir Hasrol et al. (2018), with the in-service training to civil servants can improve themselves the concept of lifelong education in fulfilling their responsibilities this learning method where sharing ideas and knowledge will be easily achieved through organized programs under the agency MyGOVUC (2021). The enforcers now have a variety of learning methods, not only courses that need to be attended in one location but now courses through the M-Learning that can be followed anytime and anywhere using BYOD concepts.

\section{The need for M-Learning through the BYOD concept is due to limited reference sources.}

The study found that the enforcement requires access to reference sources through BYOD to make inspection references during enforcement activities and inspections. This is because, until now, they do not have relevant centralized reference sources provided to assist enforcers in obtaining references. Not only it is used by the new enforcers on duty but also required by all enforcers to conduct checks and confirmations when inspections are ongoing. For example, the enforcers need to confirm information regarding the type of offense and the amount of compound that needs to be determined under the Act offenses (MDTCA., 2021g) convicted. With this, M-Learning provides the platform to the enforcers as a reference source that can be accessed through the BYOD enforcers. M-Learning can add value to the existing learning management system, which increases the acceptance of M-Learning and that employees have integrated with mobile learning through their devices to improve their knowledge and skills (Alajmi et al., 2019).

Accordingly, with the sharing of information through the BYOD concept, the enforcers can review and validate the information from time to time. Enforcers will be more confident to make inspections because the knowledge and skills required during inspections are only made through BYOD. The review includes guidelines, acts, and standard operating procedures (MDTCA., 2021h). As supported by Basir Hasrol et al. (2018), employees need to be motivated to improve themselves by knowing the culture of reading and learning the latest skills to face the progress of globalization. Also, it can indirectly improve the quality of work comprehensively and benefit the employer.

\section{Conclusions}

Researchers used a triangulation approach to evaluate semi-structured interview data, which included thematic data from interviews with respondents, a list of yearly course training, and a job confirmation examination record slip for career path improvement. Interview data will be coded to the sub-theme and subcategories to get the theme of the study. Then the interview data will be revalidated, meaning and voice by all respondents in the preliminary analysis study through the application. The usage of UTAUT2 Venkatesh et al. (2016) constructs in application design and development will be employed in this study through M-Learning, which will be built for MDTCA Enforcement Officers to follow professional training exclusively through their own devices using the BYOD concept. There are seven 
independent variables, one dependent variable and one moderator enabler to see the level of acceptance of M-Learning among Enforcement Officers.

Based on the need for the BYOD concept through M-Learning, enable the enforcers to follow courses related to the MDTCA Act MDTCA., (2021i) it is due to the factors, constraints, and duty workload. This factor is due to the many workloads and because of the difficulty to the enforcers to attend the courses offered where the course needs to be attended according to location. Time constraints to attend the course far from the office and require their finance first to attend the course. The next factor is related to the limited course offer where course offers are only offered by the headquarters, and the course offers designated zones every year. Therefore, the presence of M-Learning will help the enforcers carry out enforcement activities and improve knowledge and skills via BYOD continuously. M-learning has become a popular learning medium because it can be accessed at any time and location where this concept is also practiced in the public sector servants (Yin Ling et al., 2018b).

Regarding the implications from this study, in general to civil servants and, in particular, MDTCA enforcers will have new learning methods to follow courses through M-Learning with the concept of BYOD. Enforcers will be more confident in completing their assigned duties because they have adequate knowledge and skills due to the reference and guidelines given by their devices, and competence course attendance will be enhanced. The increase of knowledge and skills among civil servants can provide effective services and delivery to the public with quality and productivity. Finally, a wider study can be conducted, especially in overcoming the problem of the attendance of civil servants to attend the courses identified and improve the existing opportunities to strengthen M-Learning methods further.

\section{Acknowledgments}

This study is being supported by the Director MDTCA and Director of Enforcement Officer MDTCA Penang, and thanks a lot for the cooperation.

\section{References}

Ahmad Albloush., Ghassan Al-Utaibi., Sadi Taha., Abdelrahim Nassoura., Alhareth., 2020. Taming Wasta Training Opportunities in Jordan. Asian Journal of Business and Accounting. https://ajba.um.edu.my/article/view/17381

Ahmad Samed., Amr Al-Madadha2, Zahra., 2018. Modeling Student's Readiness to Adopt Mobile Learning in Higher Education: An Empirical Study. International Review of Research in Open and Distributed Learning https://files.eric.ed.gov/fulltext/EJ1174054.pdf

Asri Marsidi, Hamrila., 2007. Faktor-faktor yang Mempengaruhi Komitmen Pekerja di Organisasi Awam. Jurnal Kemanusiaan. https://www.researchgate.net/.../41805986

Chang, A. (2012). UTAUT and UTAUT 2: A Review and Agenda for Future Research. The Winners, 13(2), 10. https://doi.org/10.21512/tw.v13i2.656

Daniel, C. O. (2020). Effects of job stress on employee's performance. May.

Etikan, I. (2016). Comparison of Convenience Sampling and Purposive Sampling. American Journal of Theoretical and Applied Statistics, 5(1), 1. https://doi.org/10.11648/j.ajtas.20160501.11 
Hasan Tinmaz., Jin Hwa Lee., 2019. A Perceptional Analysis of BYOD (Bring Your Device) for Educational or Workplace Implementations in a South Korean Case. Educational Research. https://dergipark.org.tr/en/download/article-file/817760

Hasrol Basir., Mohd Salihin., Mohd Faeez., Mohd Amin., 2018. Kesedaran Penjawat Awam Terhadap Keperluan Pendidikan Sepanjang Hayat: Satu Sorotan Kajian. Conference Paper https://www.researchgate.net/publication/329862305

Huang, M. (2020). A Digital Native's Experience of Mobile Assisted Language Learning: A Reflection on a Qualitative Pilot Study. December.

Mahat, N. B., \& Ali, N. B. (2018). Empowering employees through BYOD: Benefits and challenges in Malaysian Public Sector. International Journal of Engineering and Technology(UAE), 7(4), 643-649. https://doi.org/10.14419/ijet.v7i4.35.23077

Marcel F. van Assen., 2020. Training, Employee Involvement, and Continuous Improvement - The Moderating Effect of a Common Improvement Method. Production Planning and Control. https://doi.org/10.1080/09537287.2020.1716405

Marziana Abdul., Zulkefli Mansor., Rossilawati Sulaiman., 2018. Pemerhatian Awalan ke atas Amalan Membawa Peralatan Sendiri (BYOD) dalam Organisasi di Malaysia. Universiti Kebangsaan Malaysia. http://fstm.kuis.edu.my/icits/18/eproceeding/index.html

Ministry of Domestic Trade and Consumer Affairs. Act/ Policies/ Guidelines. (2021a) (2021b) (2021c) (2021d) (2021e) (2021f) (2021g) (2021h) https://www.MDTCA.gov.my/en/public/acts-policies-guidelines.html Date of access: 8/04/2021

M. Mohamad1, F. Maringe2, J. Woollard1. 2012. Mobile Learning in Malaysian Schools: Opportunities and Challenges of introducing teaching through mobile phones International Journal for e-Learning Security (IJeLS), Volume 2, Issue 1

Mohd Nasir., Hazirah Zolkiply., 2017. Working Environment and Workers' Commitment at Keretapi Tanah Melayu Berhad (KTMN) Kuala Lumpur. Journal of Social Sciences and Humanities. https://ejournal.ukm.my/ebangi/article/view/22585

MyGOVUC Komunikasi Bersepadu. ePembelajaran http://www.1 govuc.gov.my/muat-turun/

Norazlin Mohd., Siti Rahaimah., 2019. Amalan dan Cabaran Perlaksanaan Pembelajaran Abad Ke-21. Universiti Pendidikan Sultan Idris. https://www.tatiuc.edu.my/assets/files/ICTM19-Papers/ICTM-09.pdf

Rafiq, K. R. M., Hashim, H., Md Yunus, M., \& Norman, H. (2020). iSPEAK: Using mobile-based online learning course to learn "english for the workplace." International Journal of Interactive Mobile Technologies, 14(8), 1931. https://doi.org/10.3991/IJIM.V14I08.13185

Rodriguez, J., \& Walters, K. (2017). The Importance of Training and Development in Employee Performance and Evaluation. International Journal Peer Reviewed Journal Refereed Journal Indexed Journal UGC Approved Journal Impact Factor, 3(10), 206-212. https://www.researchgate.net/publication/332537797\% $\underline{\text { 0Awww.wwjmrd.com }}$

Safie, A. B., Mohd Arshad, M. R., \& Idris, N. B. (2018). Acceptance Factor of Mobile Learning Application for Adult Learners in Life Long Learning Education. Journal of Physics: Conference Series, 1019(1). https://doi.org/10.1088/1742-6596/1019/1/012070

Syed Ardi., Dr.Zaidatun, 2017. Pembelajaran Masa Depan - Mobile Learning (M-Learning) Di Malaysia. Universiti Teknologi Malaysia. http://eprints.utm.my/id/eprint/7989/1/EDUPRES \%28F3\%29 9.pdf

Tran, C. T. H., Tran, H. T. M., Nguyen, H. T. N., Mach, D. N., Phan, H. S. P., \& Mujtaba, B. G. (2020a) (2020b). Stress Management in the Modern Workplace and the Role of Human Resource Professionals. Business Ethics and Leadership, 4(2), 26-40. https://doi.org/10.21272/bel.4(2).26-40.2020 
Yin Ling, A. M., Wan Ahmad, W. F., \& Hashim, A. S. (2018a) (2018b). Readiness of Mobile Learning among Working Adults in Malaysia. 2018 4th International Conference on Computer and Information Sciences: Revolutionizing Digital Landscape for Sustainable Smart Society, ICCOINS 2018 - Proceedings, November, 2-7. https://doi.org/10.1109/ICCOINS.2018.8510590

Yuen, S. C., \& Yuen, P. K. (2008). Mobile learning. In L. A. Tomei (Ed.), Encyclopedia of information technology curriculum integration. Hershey, PA: Idea Group.

Venkatesh, V., Thong, J. Y. L., \& Xu, X. (2016). Unified theory of acceptance and use of technology: A synthesis and the road ahead. Journal of the Association for Information Systems, 17(5), 328-376. https://doi.org/10.17705/1jais.00428 